\title{
ONE-DIMENSIONAL MATHEMATICAL MODELING OF THE CAPSULE FLOW IN A HORIZONTAL PIPE
}

\author{
ENODIMENZIONALNO MATEMATIČNO MODELIRANJE \\ PRETOKA LEDENIH KAPSUL V HORIZONTALNEM CEVOVODU
}

\author{
Zuhal Akyürek* \\ Burdur Mehmet Akif Ersoy University, Faculty of Engineering and Architecture, Istiklal Campus, 15030 Burdur, Turkey \\ Prejem rokopisa - received: 2018-10-12; sprejem za objavo - accepted for publication: 2019-03-11
}

doi:10.17222/mit.2018.221

\begin{abstract}
Horizontal hydraulic transport of ice particulates suspended in water is a well-known practice used for cooling systems in industry. Many advantages of hydraulic transport include its environmentally friendly application and a relatively low cost of maintenance and operation. This study presents a one-dimensional mathematical model, developed for simulating a pressure drop of solid and water two-phase fluid flow inside a horizontal pipe. The impact of different parameters such as suspension-wall friction coefficients, suspension-viscosity models and solid volumetric concentrations on the pressure drop of the capsule flow were evaluated. The results of the simulations were validated by the results of two different experiments. The first experiment was performed with anomalous-shaped capsules, which had a higher density than the density of the liquid flow while the second experiment was performed with capsules having a spherical shape and a density lower than the density of the carrier liquid flow in the pipe. The measurements were carried out in the horizontal pipe. In both experiments, the carrier fluid was water. The results of this modeling study revealed that the proposed model can be effectively used to predict the pressure drop of ice and water two-phase flow with sufficient precision.

Keywords: two-phase flow, pressure drop, capsule flow, suspension viscosity
\end{abstract}

Horizontalni hidravlični transport delcev ledu v vodni raztopini je dobro znana praksa, uporabljena $\mathrm{v}$ industrijskih hladilnih sistemih. Hidravlični transport je okolju prijazen in ima mnoge prednosti zaradi relativno nizkih stroškov obratovanja in vzdrževanja. Avtorji predstavljajo študijo enodimenzionalnega matematičnega modela, ki so ga razvili za simulacijo padca tlaka $\mathrm{v}$ horizontalnem cevovodu med pretakanjem dvofaznega medija (suspenzija trdno/kapljevina). Ovrednotili so vpliv različnih parametrov, kot so koeficienti trenja med steno in suspenzijo, modelov za viskoznost suspenzije in volumske koncentracije na padec tlaka med pretokom ledu v obliki kapsule. Veljavnost rezultatov simulacij so ocenili s pomočjo podatkov, dobljenih z dvema različnima eksperimentoma. Prvi eksperiment so izvedli z nepravilno obliko kapsul, ki ima višjo gostoto kot pretok same kapljevine. Drugi eksperiment pa je bil izveden s kroglično obliko kapsul in nižjo gostoto, kot jo ima dejanski nosilni medij v cevovodu. Vse eksperimentalne meritve so bile izvedene $\mathrm{v}$ horizontalnem cevovodu. $\mathrm{V}$ obeh primerih je bila voda nosilni medij. Rezultati modelnih študij so pokazali, da lahko predlagani model z zadovoljivo natančnostjo učinkovito uporabimo za napoved padca tlaka pri pretoku dvofaznega (led in voda) medija.

Ključne besede: dvofazni pretok, padec tlaka, pretok kapsul, viskoznost suspenzije

\section{INTRODUCTION}

Hydraulic transport of capsules in pipelines have become a subject of intense research in recent decades. Capsule transportation through horizontal pipelines is employed in many engineering processes. ${ }^{1-9}$ Two-phase flow of ice and water in cylindrical tubes is most widely used in cooling systems in industry. ${ }^{10}$ The use of icewater slurries in district cooling systems can be considered as one of the most crucial technical improvements for the industrial development. In addition, global-warming impacts of chemical refrigerants, especially ozone-depletion concerns caused the refrigeration industry to search for environmentally friendly refrigerant options. ${ }^{11}$ Moreover, ice-water slurry has a much higher energy capacity compared to the conventional chilled-water systems and it produces a much greater cooling potential at the same pumping cost. ${ }^{12}$ On the

*Corresponding author's e-mail:

drzuhalakyurek@gmail.com other hand, using ice capsules is much more advantageous compared to ice slurries due to a lack of dispersion of the particles leading to a blockage in the pipes. The cooling capacity in district systems can be improved by using ice capsules instead of ice slurries due to their high concentration and flow velocity. In the literature, several studies focused on the hydrodynamic behavior of a twophase ice-water flow ${ }^{1,4-10,13-16}$ and also on the transfer of heat during the capsule flow. ${ }^{12,17-20}$

Vast studies on two-phase ice-water flow experiments are available in the literature; however, investigations on the characterization of flow behavior are very limited. This is mainly due to high complexity of the mathematical modeling of two-phase flow such as ice and water. ${ }^{7,17,21,22}$ Intensive research is required to precisely understand and be able to make prediction on the flow behavior, and to search for the ways of improving their processing. Therefore, the motivation behind this study was developing a one-dimensional mathematical model to simulate the pressure drop of the flow of an ice-water 


\section{Z. AKYÜREK: ONE-DIMENSIONAL MATHEMATICAL MODELING OF THE CAPSULE FLOW IN A HORIZONTAL PIPE}

two-phase mixture inside a horizontal pipe. In the modeling study, the parameters having a high impact on the pressure drop of a capsule flow system such as suspension-viscosity model, suspension-wall friction coefficient and volumetric concentrations were investigated. The results of the developed mathematical model were validated with two different sets of experimental data obtained from the literature. The first set of data ${ }^{13}$ (A) referred to a capsule flow of an anomalous shape having a higher density than the fluid, and the second set of data ${ }^{15}$ (B) was adopted from an experiment performed with spherical-shaped capsules having a lower fluid density.

\section{MODEL DESCRIPTION}

Modeling of two-phase flows such as ice and water is a challenging process due to the fact that it depends on many factors, resulting in a wide range of flow regimes. Therefore, developing a simplified model, which can describe the two-phase flow of an ice-water system with a suitable precision is necessary. In this respect, a onedimensional mathematical model is developed and solved with the Gauss-Seidel method using MATLAB.

The assumptions presented below were made to solve the governing equations in the model for the capsulecarrying pipeline:

Assumption 1: Homogenous flow

Assumption 2: Fully developed flow

Assumption 3: The influence of the heat transfer/ pressure drop along the pipe on the solid-phase concentration is negligible

Assumption 4: Buoyancy effects of the phases differ

Assumption 5: The suspension-wall friction is independent of the water temperature

Figure 1 shows a schematic illustration of an icewater flow. As can be seen from the figure, a control volume is defined within the pipe where the ice-water two-phase flow is modeled.

A flow chart of the model is presented in Figure 2. The figure includes all the governing equations and cor-

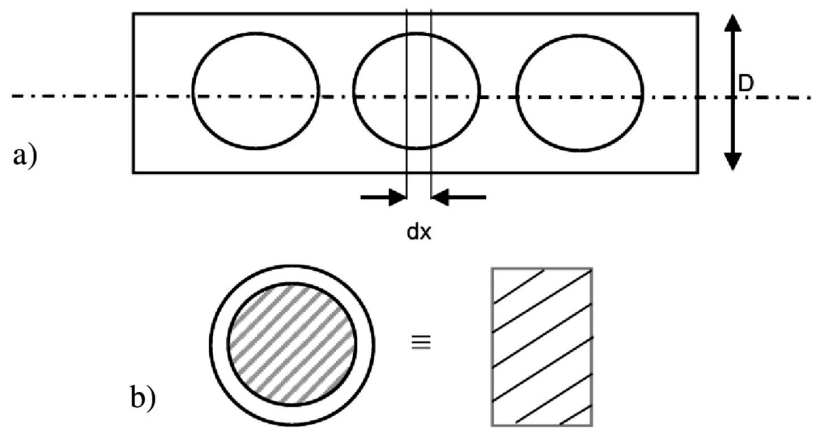

Figure 1: Schematic illustration of the spherical capsule in a pipe flow: a) the side view of the pipe, b) the front view of the pipe and its equivalent control volume

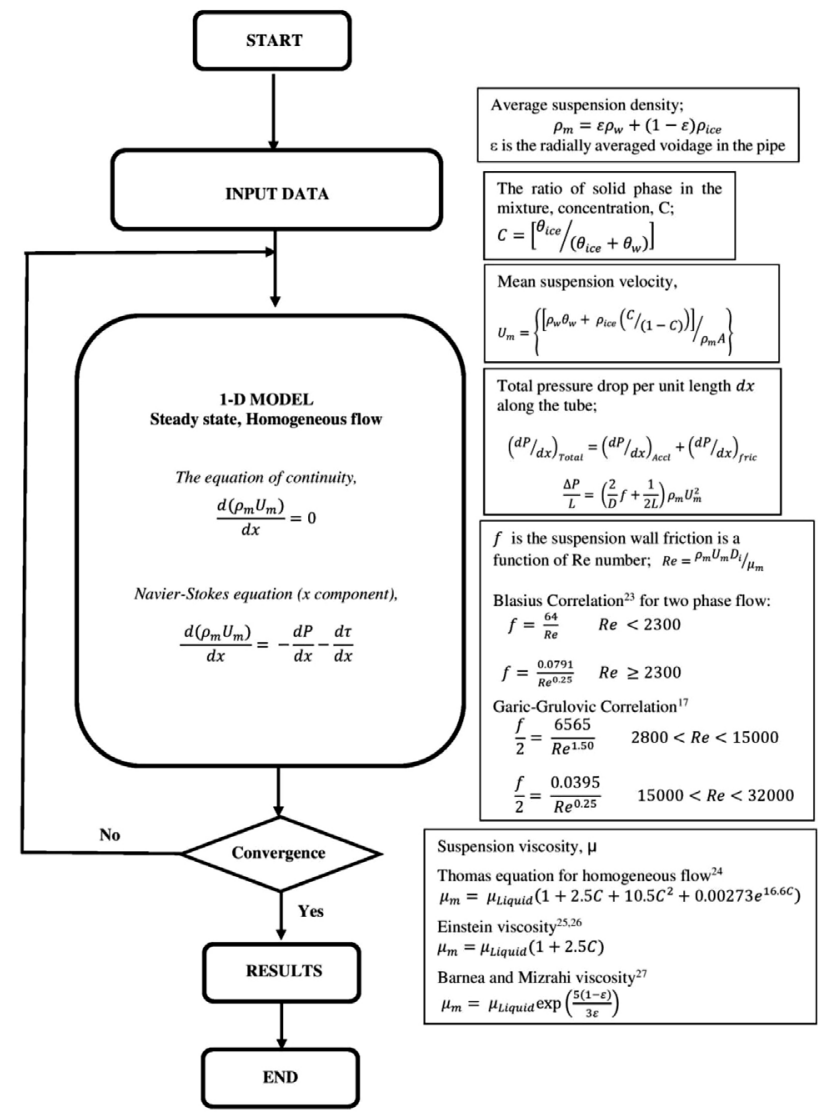

Figure 2: Flow chart of the modeling study

relations for the steady-state one-dimensional homogeneous equilibrium flow in a horizontal pipe.

\section{RESULTS AND DISCUSSION}

The mathematical model of a homogenous two-phase flow developed in this study was validated with the published experimental data. ${ }^{13,15}$ In the experiments, two-phase capsule-flow measurements were carried out in a horizontal straight pipe (plexiglass) where water was the carrier fluid. In the first set of experiments, ${ }^{13}$ the accuracy of the liquid velocity was found to be about $2.5 \%$, whereas the accuracy of the capsule velocity was $1.5 \%$. During the pressure-drop measurements, the accuracy of was about $3 \%$. Anomalous-shaped capsules having their density greater than that of the carrier liquid were used in these experiments. With the second data set, ${ }^{15}$ spherical capsules, fabricated from polypropylene having their density lower than that of the water were used. In this study, the flow rate was measured with water flow meters having an average deviation of $0.5 \%$ (max. $0.1 \%$ ) from the actual values. The measurements of the pressure drop were carried out on a 4-m section of the pipe. The ratio of the capsule diameter to the pipe diameter $(\mathrm{d} / \mathrm{D})$ was 0.8 . The main parameters used in the experiments and the conditions are given in Table $\mathbf{1}$. 
Table 1: Parameters used in experimental studies

\begin{tabular}{|l|c|c|}
\hline & Experiment $\mathrm{A}^{13}$ & Experiment $\mathrm{B}^{15}$ \\
\hline \multicolumn{1}{|c|}{ Capsule geometry } & Anomalous & Spherical \\
\hline$L(\mathrm{~m})$ & 2 & 4 \\
\hline$D(\mathrm{~m})$ & 0.05 & 0.1 \\
\hline$d / D(-)$ & 0.8 & 0.8 \\
\hline$\rho_{\mathrm{c}}\left(\mathrm{kg} / \mathrm{m}^{3}\right)$ & 1200 & 870 \\
\hline$C(-)$ & $0.20-0.50$ & $0.05-0.30$ \\
\hline Reynolds number $(-)$ & $2.5 \times 10^{4}<\mathrm{Re}<$ & $1.2 \times 10^{4}<\mathrm{Re}<$ \\
& $1.5 \times 10^{5}$ & $1.5 \times 10^{5}$ \\
\hline Fluid temperature $\left({ }^{\circ} \mathrm{C}\right)$ & 20 & 20 \\
\hline
\end{tabular}

For the model validations, the suspension viscosity and suspension-to-wall friction values were calculated with the formulas given in Figure 2.

The comparison of the simulation results for the first experimental data are shown in Figure 3. As can be seen
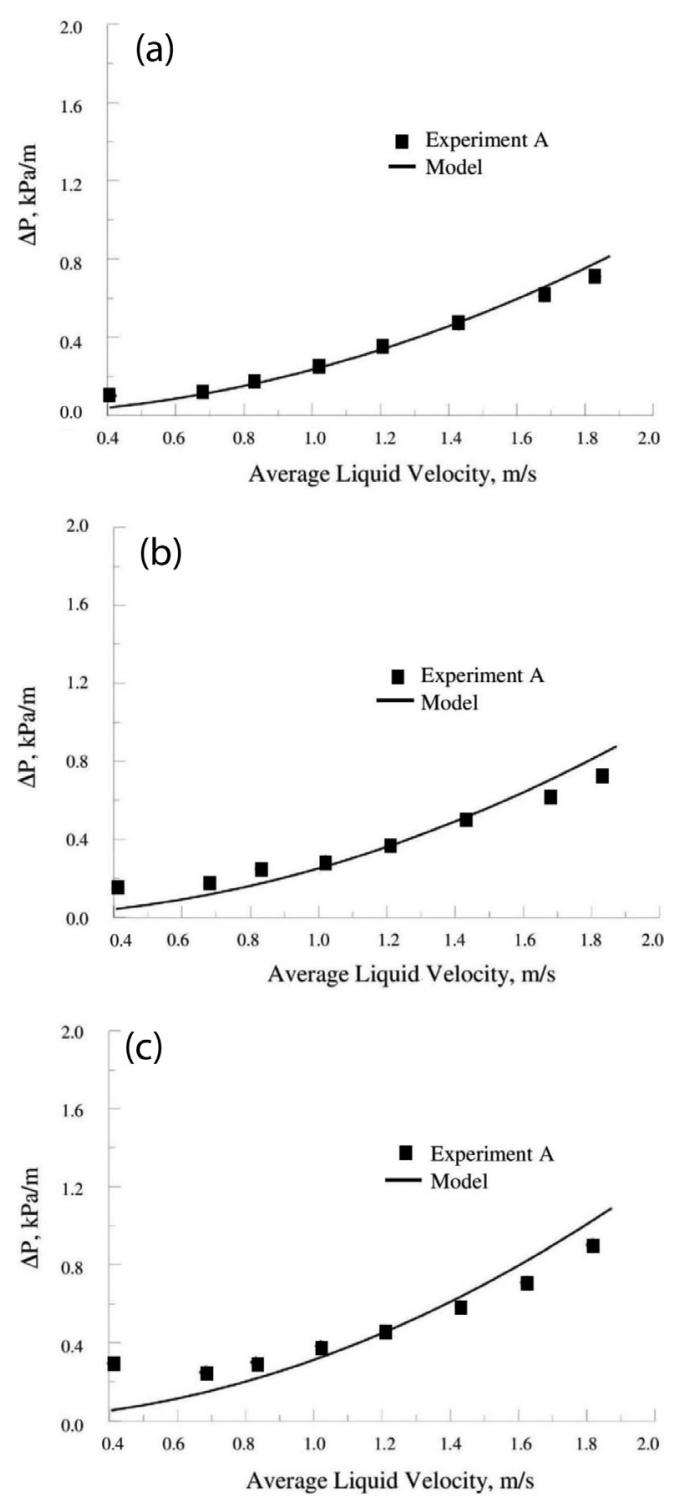

Figure 3: Comparison of simulation results for experimental data set A at different concentrations: a) $\mathrm{C}=0.20$, b) $\mathrm{C}=0.30$, c) $\mathrm{C}=0.50$ from the figure, for the capsule flow of an anomalous shape and having a higher density than the carrier-liquid density, the increasing average velocity of the carrier resulted in an increase in the pressure drop. The simulation results are in good agreement with the experimental results at capsule concentrations of $(0.20,0.30$ and 0.50$)$.

The simulation results of pressure-drop calculations give a sufficient accuracy at low capsule concentrations. The anomalous-capsule concentration is greater than $30 \%$, the solution diverges and the accuracy reduces. Interactions within the phases change the hydrodynamic behavior of the flow. For the pressure-drop simulations at higher concentrations, a separate flow model can be applied. In this study, a homogenous-flow approximation is used in order to have a vision about the variation in the pressure drop of the capsule flow.

The comparison of the simulation results for experimental data set B are given in Figure 4. In this set, spherical capsules having a lower density than the water were carried by the flowing fluid in the pipe. As it can be seen from the figure, the simulation results are in good agreement with the experimental data. The increase in the carrier velocity resulted in a higher pressure drop at capsule concentrations of $(0.05,0.10,0.15$ and 0.20$)$. The results of the simulation showed a small discrepancy at capsule concentrations of $(0.05$ and 0.20$)$ values.

In the two-phase flow of ice-water capsule system, parameters such as suspension-to-wall friction coefficients and solid-phase concentrations $(\phi / \%)$ have a significant impact on the analysis of the pressure drop. Different suspension-viscosity models and suspensionto-wall friction coefficients were applied in order to investigate the change in the pressure drop of the two-phase ice-water mixture. The cases analyzed (Case 1 and Case 2) are shown in Table 2. In the model validation, Case $2 \mathrm{~b}$ was considered as the base case. Spherical particles of ice with a $0.08 \mathrm{~m}$ diameter and water as the carrier were used in the analyses. The temperature of the carrier was taken as $20{ }^{\circ} \mathrm{C}$ for various Cases related to
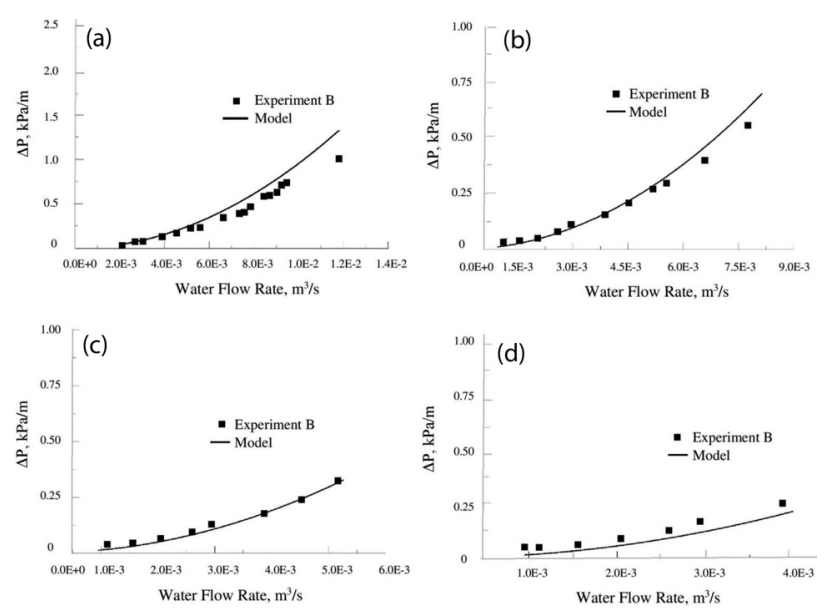

Figure 4: Comparison of simulation results for experimental data set $\mathrm{B}$ at different concentrations: a) $\mathrm{C}=0.05$, b) $\mathrm{C}=0.10$, c) $\mathrm{C}=0.15$, d) $\mathrm{C}=0.20$ 


\section{Z. AKYÜREK: ONE-DIMENSIONAL MATHEMATICAL MODELING OF THE CAPSULE FLOW IN A HORIZONTAL PIPE}

the suspension viscosity (Cases $1 \mathrm{~b}$ and $2 \mathrm{~b}$ ) and to the suspension-wall friction factors (Cases $1 \mathrm{a}$ and $1 \mathrm{~b}$ ) at capsule concentrations within the range of 0.05-0.25.

Figure 5 presents the impact of the suspension-towall friction factor on the pressure drop. As can be seen from the figure, the pressure-drop variation, with respect to the Reynolds number, follows a similar trend in both Cases (1b and 2b). When the Blasius friction-factor correlation was used in the pressure-drop calculations, a deviation from the actual values was observed, especially at high Reynolds-number values.

Table 2: Cases considered in the model $1^{17,23,24-27}$

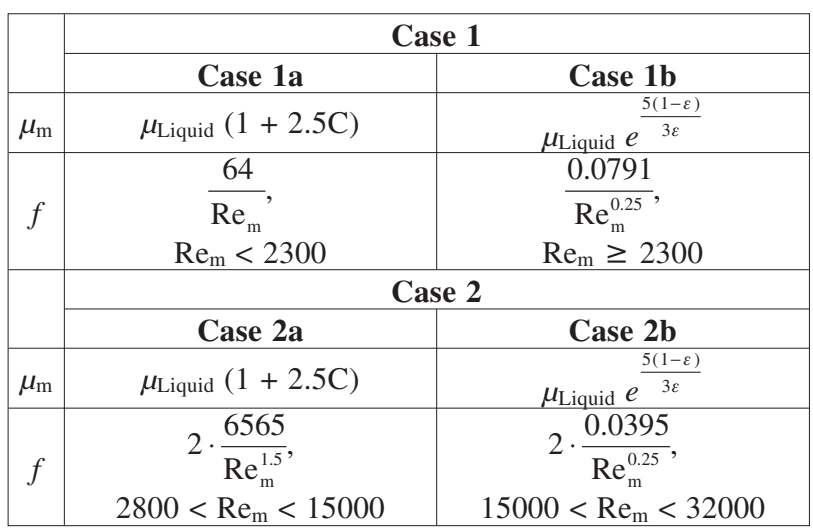

The pressure-drop variation, with respect to the empirical suspension-viscosity formulations, is presented in Figure 6 for Cases 1a and 1b. Both formulations showed to have a similar impact on the pressure drop of the ice-water two-phase mixture under consideration. The maximum variation in the pressure drop amounted to $10.7 \%$. This implies that for the ice-water mixtures both formulations can be applied to homogeneous model calculations. The impact of the suspension viscosity and suspension-to-wall friction on the pressure drop was found to be greater at high values of the Reynolds number whereas no significant impact of these factors on the pressure drop was observed at low values of the Reynolds number.

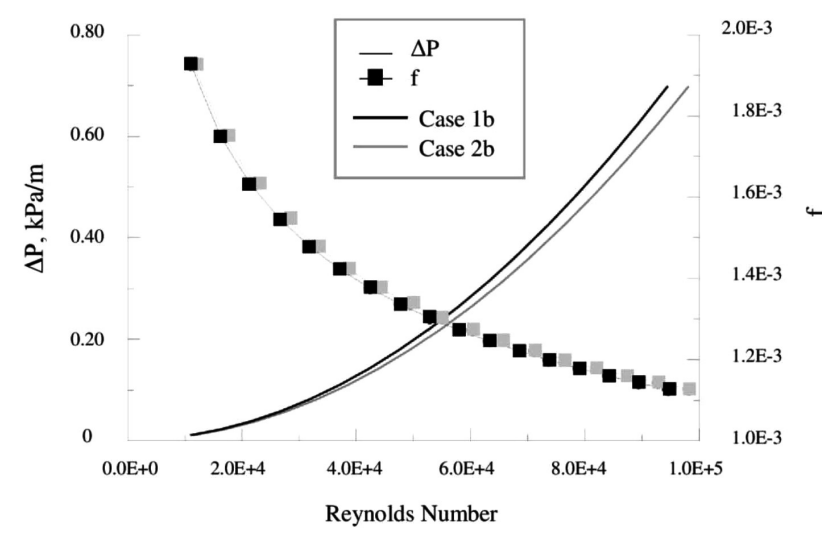

Figure 5: Effect of suspension-wall friction coefficients on the pressure gradient (spherical capsules, $\mathrm{d} / \mathrm{D}=0.8, \mathrm{C}=0.10$ )

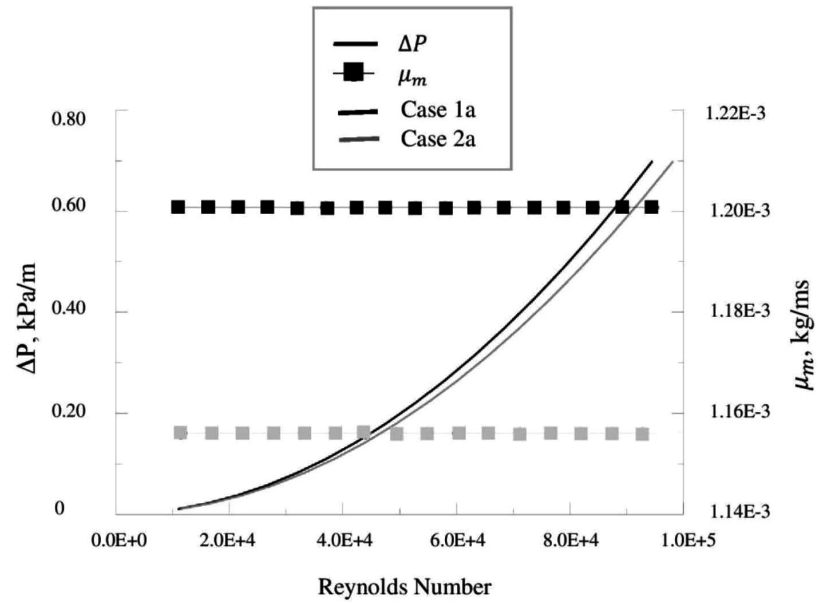

Figure 6: Effect of suspension viscosities on the pressure gradient ( spherical capsules, $\mathrm{d} / \mathrm{D}=0.8, \mathrm{C}=0.10$ )

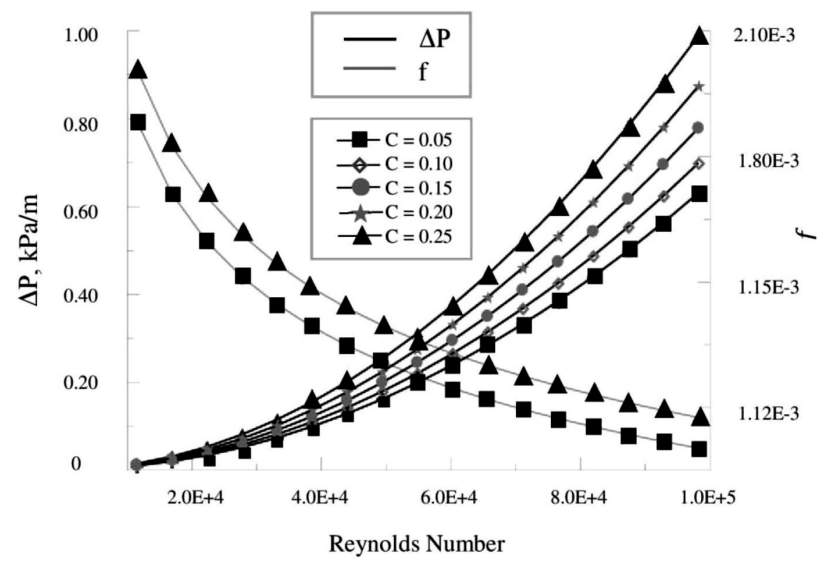

Figure 7: Effect of volumetric solid concentration on the pressure gradient (base case, spherical capsules, $d / D=0.8$ )

The pressure-drop variation with the capsule concentration of the ice-water two-phase mixture is shown in Figure 7. As can be seen from the figure, higher capsule concentrations resulted in higher pressure gradients. The pressure drop also reached higher values with the increase in the Reynolds number. The increase in the concentration raised the impact of the friction factor.

\section{CONCLUSIONS}

The modelling of two-phase flows is a challenging and complex process, especially for liquid-solid flows. Therefore, a simplified model has to describe the icewater two-phase flow characteristics with a satisfactory accuracy. In this regard, in the present study, a onedimensional model was developed as the first approximation. In the simulation model, the pressure drop during the ice-water two-phase-mixture flow inside the pipe is described. The impact of different suspensionviscosity models, suspension-wall friction coefficients and volumetric capsule concentrations on the pressure drop of the capsule flow were investigated throughout 
the study. The simulation results were also validated with the results obtained from two different experimental studies. One of the experiments was performed with capsules having an anomalous shape and density greater than the density of the carrier liquid and the other one was performed with spherical-shaped capsules with a density lower than the carrier liquid. In both experiments, measurements were carried out in a horizontal, straight plexiglass pipe and water was used as the carrier. This study revealed that a steady-state, homogenous model approach can be used with confidence for the calculations of the pressure drop of the solid-liquid two-phase mixture in a horizontal pipe. The model results are reliable, especially for the spherical capsules at a volumetric concentration of up to $25 \%$ and for anomalous capsules at concentrations lower than $50 \%$. The suspension-wall friction factor ${ }^{17}$ and suspension-viscosity models ${ }^{27}$ used in the calculations were found to be applicable to the pressure-drop calculations for solidliquid two-phase mixtures.

\section{Acknowledgement}

This research did not receive any specific grant from the funding agencies in the public, commercial or nonprofit sectors. The author would like to thank Professor Dr. Afsin Güngör for his valuable comments.

\section{REFERENCES}

${ }^{1}$ Y. Zheng, J. X. Zhu, J. Wen, S. A. Martin, A. S. Bassi, A. Margaritis, The axial hydrodynamic behavior in a liquid-solid circulating fluidized beds, Can. J. Chem. Eng., 77 (1999), 284-290, doi:10.1002/cjce.5450770213

${ }^{2}$ Q. Lan, A. S. Bassi, J. X. Zhu, A. Margaritis, Continuous protein recovery with a liquid-solid circulating fluidized bed ion exchanger, AIChE J., 48 (2002), 252-261, doi:10.1002/aic.690480209

${ }^{3}$ D. G. Karamanev, T. Nagamune, I. Endo, Hydrodynamic and mass transfer study of a gas-liquid-solid draft tube spouted bed bioreactor, Chem. Eng. Sci., 47 (1992), 3581-3588, doi:10.1016/0009-2509 (92)85073-K

${ }^{4}$ P. A. Shamlou, Hydraulic transport of particulate solids, Chem. Eng. Commun., 62 (1987), 233-240, doi:10.1080/00986448708912062

${ }^{5}$ M. S. Seki, R. Skalak, Asymmetric flows of spherical particles in a cylindrical tube, Biorheology, 3 (1997), 155-169, doi:10.1016/ S0006-355X(97)00023-1

${ }^{6}$ M. S. Seki, Motion of a sphere in a cylindrical tube filled with a brinkman medium, Fluid Dyn. Re., 34 (2004), 59-76, doi:10.1016/ j.fluiddyn.2003.08.007

${ }^{7}$ S. K. Mishra, C. Handra, A. Arora, Complex internal fluid flow behavior, Int. J. Adv. Man. Tech. and Eng. Sci., 8 (2018), 1461-1467

${ }^{8}$ T. Asim, A. Algadi, R. Mishra, Effect of capsule shape on hydrodynamic characteristics and optimal design of hydraulic capsule pipelines, J. Pet. Sci. Eng., 161 (2018), 390-408, doi:10.1016/ j.petrol.2017.12.001

${ }^{9}$ T. Asim, R. Mishra, S. Abushaala, A. Jain, Development of a design methodology for hydraulic pipelines carrying rectangular capsules, Int. J. Pres. Ves. Pip., 146 (2016), 111-128, doi:10.1016/j.ijpvp. 2016.07.007

${ }^{10}$ D. Uluarslan, Experimental investigation of the effect of diameter ratio on velocity ratio and pressure gradient for the spherical capsule train flow, Eur. J. Mech. B/Fluids, 37 (2013), 42-47, doi:10.1016/ j.euromechflu.2012.05.004

${ }^{11}$ P. W. Egolf, M. Kauffeld, From physical properties of ice slurries to industrial ice slurry applications, Int. J. Refrig., 28 (2005), 4-12, doi:10.1016/j.ijrefrig.2004.07.014

${ }^{12}$ B. D. Knodel, D. M. France, U. S. Choi, M. W. Wambsganss, Heat transfer and pressure drop in ice-water slurries, Appl. Therm. Eng., 20 (2000), 671-685, PII: S1359-4311(99)00046-0

${ }^{13} \mathrm{P}$. Vlasak, An experimental investigation of capsules of anomalous shape conveyed by liquid in a pipe, Powder Technol., 104 (1999), 207-213, doi:10.1016/S0032-5910(99)00096-0

${ }^{14}$ A. E. Vardy, J. M. B. Brown, Transient turbulent friction in fully rough pipe flows, J. Sound Vib., 270 (2004), 233-257, doi:10.1016/ S0022-460X(03)00492-9

${ }^{15}$ D. Ulusarslan, I. Teke, An experimental investigation of the capsule velocity, concentration rate and the spacing between the capsules for spherical capsule train flow in a horizontal circular pipe, Powder Technol., 159 (2005), 27-34, doi:10.1016/j.powtec.2005.05.059

${ }^{16}$ D. Ulusarslan, I. Teke, An experimental determination of pressure drops in the flow of low density spherical capsule train inside horizontal pipes, Exp. Therm. Fluid Sci., 30 (2006), 233-241, doi:10.1016/j.expthermflusci.2005.07.003

${ }^{17}$ R. V. Garic-Grulovic, Z. B. Grbavcic, Z. L. Arsenijevic, Heat transfer and flow pattern in vertical liquid-solids flow, Powder Technol., 145 (2004), 163-171, doi:10.1016/j.powtec.2004.07.006

${ }^{18}$ K. A. R. Ismail, J. R. Henriquez, Solidification of PCM inside a spherical capsule, Energy Convers. Manag., 41 (2000), 173-187

${ }^{19}$ A. V. Wilchinsky, S. A. Fomin, T. Hashida, Contact melting inside an elastic capsule, Int. J. Heat Mass Transfer, 45 (2002), 4097-4106

${ }^{20}$ Y. Huo, Z. Rao, Investigation of solid-liquid phase change in the spherical capsule using axisymmetric lattice Boltzmann model, Int. J. Heat Mass Transfer, 119 (2018), 1-9, doi:10.1016/j.ijheatmasstransfer.2017.11.099

${ }^{21}$ J. Ling, P. V. Skudarnov, C. X. Lin, M. A. Ebadian, Numerical investigations of liquid-solid slurry flows in a fully developed turbulent flow region, Int. J. Heat Fluid Fl., 24 (2003), 389-398, doi:10.1016/S0142-727X(03)00018-3

${ }^{22}$ V. Gnielinski, Forced convection in ducts, Handbook of Heat Exchanger Design, Begell House, New York 1992

${ }^{23}$ R. B. Bird, W. E. Steward, E. N. Lightfoot, Transport Phenomena, J. Wiley, New York 1960

${ }^{24}$ D. G. Thomas, Transport characteristics of suspension, J. Colloid Sci., 20 (1965), 267-277, doi:10.1016/0095-8522(65)90016-4

${ }^{25}$ A. Kitanovski, A. Poredos, Concentration distribution and viscosity of ice-slurry in heterogeneous flow, Int. J. Refrig., 25 (2002), 827-835, doi:10.1016/S0140-7007(01)00091-3

${ }^{26}$ H. A. Barnes, An introduction to rheology, Elsevier, Amsterdam 1989

${ }^{27}$ E. Barnea, J. Mizrahi, A generalized approach to the fluid dynamics of particulate systems: I. General correlation for fluidization and sedimentation of solid multiparticle systems, Chem. Eng. J., 5 (1973), 171-189, doi:10.1016/0300-9467(73)80008-5

\section{Nomenclature}

A Cross-sectional area of the pipe $\left(\mathrm{m}^{2}\right)$

$f \quad$ Suspension-wall friction coefficient (dimensionless)

$C \quad$ Volumetric concentration of solid phase (dimensionless)

$d \quad$ Capsule outer diameter (m)

$D \quad$ Pipe inner diameter (m)

$l \quad$ Capsule length for anomalous capsule shapes (m)

$L \quad$ Pipe length (m)

$\dot{m} \quad$ Mass flow rate $(\mathrm{kg} / \mathrm{s})$

$P \quad$ Pressure $(\mathrm{Pa})$

$\mathrm{Re} \quad$ Modified suspension Reynolds number (m)

$U_{\mathrm{m}} \quad$ Mean velocity of two-phase mixture $(\mathrm{m} / \mathrm{s})$

$\theta \quad$ Volumetric flow rate $\left(\mathrm{m}^{3} / \mathrm{s}\right)$ 
Z. AKYÜREK: ONE-DIMENSIONAL MATHEMATICAL MODELING OF THE CAPSULE FLOW IN A HORIZONTAL PIPE

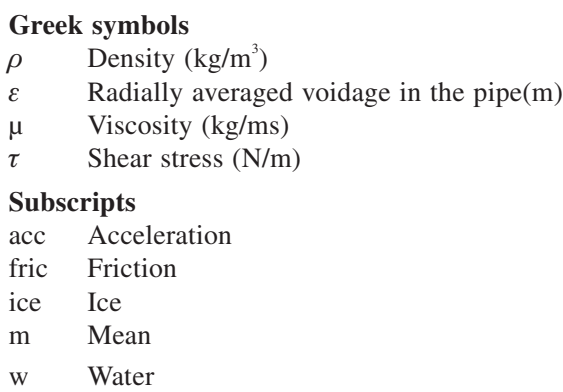

